\title{
The 2018 Fisheries White Paper, the Fisheries Act 2020 and their international legal dimension
}

\author{
Andrew Serdy* \\ Professor of the Public International Law of the Sea, University of Southampton, UK
}

The 2018 Fisheries White Paper and the Fisheries Act 2020 were designed to govern United Kingdom (UK) fisheries management in the post-Brexit era irrespective of whether the UK and the European Union (EU) succeeded in settling their differences on fisheries and other matters that for much of 2020 made it uncertain whether the Trade and Cooperation Agreement could be concluded. This article considers several international legal issues raised by the White Paper and Fisheries Act, including the choices made by the UK as to which regional fisheries management organisations to (re)join now that the EU no longer speaks for the UK within them, and the treaty processes for doing so, before moving on to further matters given only sketchy treatment in, or omitted altogether from, those documents, on which a firmer position ought to have been taken. Lastly, a new problem apparent for the first time in the Fisheries Act is discussed: navigational freedom of foreign fishing vessels in the UK's exclusive economic zone, and a missed opportunity to legislate a related evidential presumption that would assist future prosecutions for illegal fishing.

Keywords: Fisheries Act 2020, Fisheries White Paper, Trade and Cooperation Agreement, EU Withdrawal Agreement, shared stocks, regional fisheries management organisations (RFMOs)

\section{INTRODUCTION}

With the departure of the United Kingdom (UK) from the European Union (EU) on 31 January 2020 after three postponements under Article 50(3) of the Treaty on European Union (TEU), ${ }^{1}$ the future legal relationship between the UK and the EU appeared for much of 2020 to hinge on whether a small number of issues dividing them could be resolved. At first there seemed to be a trade-off between, on the one hand, how free the UK financial sector would be to offer its services within, but not be regulated by, the EU, and on the other, to what extent fishing vessels registered in any EU Member State would retain access to UK waters. ${ }^{2}$ Later the financial question lost prominence as the

* This article is based on the lecture 'Brexit and Fisheries: International Law Dimensions of the 2018 White Paper and Current Fisheries Bill' presented as the joint Cambridge International Law Journal-Lauterpacht Centre for International Law 2020-2021 Annual Lecture, delivered virtually through the Lauterpacht Centre for International Law at the University of Cambridge, UK, on 20 November 2020.

1. Consolidated Version of the Treaty on European Union [2008] OJ C115/13 (TEU).

2. Frederick Studemann, 'Fish and Finance Have More in Common Than Meets the Eye', Financial Times (London, 20 February 2020) <https://www.ft.com/content/74070226-53d111ea-8841-482eed0038b1> accessed 28 December 2020. 
issue of what limits the UK was prepared to accept on its State aid in return for continued tariff- and quota-free access to the EU market for its goods came to the fore. ${ }^{3}$ On the other side of the ledger, fishing access remained the central unsatisfied EU demand, and was the last live issue that caused the finalisation of their Trade and Cooperation Agreement ${ }^{4}$ to be delayed until only a week before the transition period under the withdrawal treaty contemplated in Article 50(2) of the TEU (hereinafter the Withdrawal Agreement ${ }^{5}$ ) expired at the end of 2020. Under the Withdrawal Agreement, the UK remained bound by the EU's Common Fisheries Policy (CFP) during the transition period; a single extension of up to two years would have been possible if it were agreed by the end of June $2020,{ }^{6}$ but this did not happen. This is not the first time that a much broader international political settlement has been made dependent on the outcome of a fisheries negotiation. Perhaps the best-known historical precedent is the fisheries treaty negotiated between the United States and Japan (as well as Canada) in $1951,{ }^{7}$ since the conclusion of such a treaty was made a condition for terminating the post-war occupation of Japan. ${ }^{8}$

The future of the UK's fisheries relationship with the EU and of its international fisheries policy more generally had already preoccupied the UK government during the 2017-2019 Parliament. This was unsurprising given that industry's prominence in the pro-Brexit camp, hoping to reverse what it sees as an historic wrong when its

3. George Parker and Jim Brunsden, 'Michel Barnier Warns "No Progress" Made on Key Issues in Brexit Talks', Financial Times (London, 23 July 2020) <https://www.ft.com/content/ 14e6c44f-5573-46c1-8f4c-224747562c42> accessed 28 December 2020.

4. Trade and Cooperation Agreement Between the European Union and the European Atomic Energy Community, of the one part, and the United Kingdom of Great Britain and Northern Ireland, of the other part (signed 30 December 2020, provisionally applied from 1 January 2021 and definitively entered into force 1 May 2021) [2020] OJ L444/14, UKTS 20218 (Trade and Cooperation Agreement). This article does not systematically analyse the Trade and Cooperation Agreement's fisheries provisions, as Department for Environment, Food \& Rural Affairs, 'Sustainable Fisheries for Future Generations' (White Paper, Cm 9660, 2018) (hereinafter the White Paper) and the Fisheries Act 2020 (UK) were designed to be equally applicable whether or not an agreement of that nature encompassing fisheries matters was ultimately concluded. The European Union (Future Relationship) Act 2020 (UK), presented to and passed by Parliament on 30 December 2020 to implement certain of its provisions in UK law, does not therefore specifically mention fisheries (although the Fisheries Act is not exempt from the sweeping general implementation powers in s 31 of the European Union (Future Relationship) Act, which enable amendment of Acts by delegated legislation for the purpose of complying with the Trade and Cooperation Agreement). (NB: the author is grateful to the publishers for the opportunity to substitute the final article numbers for the provisional ones at a very late stage in the typesetting; as the latter were unsystematically non-sequential and no table of concordances has been provided, not to have taken account of this last-minute development would have left readers unable to identify the articles concerned.)

5. Agreement on the Withdrawal of the United Kingdom of Great Britain and Northern Ireland from the European Union and the European Atomic Energy Community (signed 24 January 2020, entered into force 1 February 2020) [2020] OJ L29/7, UKTS 20203 (Withdrawal Agreement).

6. Ibid arts 126, 127(1) (first sentence) and 132(1).

7. International Convention Between the United States of America, Canada and Japan for the High Seas Fisheries of the North Pacific Ocean (signed 9 May 1952, entered into force 12 June 1953) 205 UNTS 65.

8. See generally Harry N Scheiber, 'Japan, the North Atlantic Triangle, and the Pacific Fisheries: A Perspective on the Origins of Modern Ocean Law, 1930-1953' (2004) 6 San Diego International Law Journal 27. 
interests were sacrificed in order to secure the UK's entry into what was then the European Economic Community in $1973,{ }^{9}$ combined with the fact that access to its exclusive economic zone (EEZ) was one of the few cards the UK could play in its negotiations with the EU for a free trade agreement.

Fisheries had 14 articles devoted to it in the EU's draft treaty text published in March 2020, ${ }^{10}$ supplemented by four annexes, but the UK's rival text, released in May 2020, was near-silent on the subject. The sole substantive reference to fisheries was in the wider context of subsidies,${ }^{11}$ in pursuance of the policy of keeping this question separate and negotiating the level of access a year at a time, as foreshadowed in the White Paper on sustainable fisheries published in July 2018, commonly known as the Fisheries White Paper (hereinafter the White Paper). ${ }^{12}$

Accordingly, fisheries was the subject of a separate draft agreement put forward by the UK, comprising 12 articles of relatively general substance. Its only remarkable feature was Article 9, by which either of the parties could unilaterally suspend the agreement if a dispute arises between them about it, even before invoking any process to settle the dispute, much less awaiting its outcome, requiring only the allegation by one party that the other has breached its obligations. ${ }^{13}$ The UK government was pinning its hopes on being able to persuade the EU to accept the principle of zonal attachment, the idea that quotas for each stock should be allocated so as to reflect how much of it is present in the UK's and its neighbours' EEZs over the course of a year, ${ }^{14}$ though to what extent this was achieved in the ultimately negotiated agreement, by the 25 per cent averaged cut in the EU's share of all stocks subject to quotas, ${ }^{15}$ with no further rebalancing foreseen after 2026 when the phasing-in period ends, is debatable.

9. For a polemic on this, which long predates Brexit, see Christopher Booker and Richard North, The Castle of Lies: Why Britain Must Get Out of Europe (Duckworth, London 1996) 77-90.

10. Commission, 'Draft Text of the Agreement on the New Partnership with the United Kingdom (March Draft Text)' (18 March 2020) UKTF (2020) 14, arts LPFS.2.45, FISH.1FISH.13 <https://ec.europa.eu/info/sites/info/files/200318-draft-agreement-gen.pdf>.

11. UK Government, 'Draft Working Text for a Comprehensive Free Trade Agreement Between the United Kingdom and the European Union' (May 2020) <https://assets.publishing.service.gov.uk/government/uploads/system/uploads/attachment_data/file/886010/ DRAFT_UK-EU_Comprehensive_Free_Trade_Agreement.pdf $>$ accessed 28 December 2020, art 21.4.

12. White Paper (n 4) 18, stating that 'we will decide who can access our waters after 2020 and on what terms .... Any decisions about giving access to our waters for vessels from the EU, and any other coastal states including Norway, will then be a matter for negotiation', to take place 'on an annual basis'.

13. UK Government, 'Draft Working Text for a Fisheries Framework Agreement Between the United Kingdom of Great Britain and Northern Ireland and the European Union' < https://assets. publishing.service.gov.uk/government/uploads/system/uploads/attachment_data/file/886009/ DRAFT_Fisheries_Framework_Agreement.pdf> accessed 28 December 2020.

14. White Paper (n 4) 12 and 26. See also 44-56, under the heading 'Annex C: Zonal Attachment Evidence', showing that different ways exist to measure this.

15. The 25 per cent figure is taken from the accompanying governmental document, UK Government, 'UK-EU Trade and Cooperation Agreement: Summary' (December 2020) para $125<$ https://assets.publishing.service.gov.uk/government/uploads/system/uploads/attachment_ data/file/948093/TCA_SUMMARY_PDF.pdf $>$ accessed 14 February 2021, and is not evident from arts 493 and 494 of the Trade and Cooperation Agreement (n 4) itself as no comparable shares are given for 2020. 
This contribution examines the international law aspects of the two documents which took the first steps in repositioning the UK's fisheries policy for the post-EU era, but dealt with some issues only sketchily, in a way suggestive of possible underlying misunderstandings: the aforementioned White Paper and the Fisheries Act, ${ }^{16}$ one of several statutes made necessary by the UK's departure from the EU. ${ }^{17}$ Certain passages in both documents may cause future difficulty in the way the UK goes about discharging its obligations arising from international fisheries law, to which it has had limited direct exposure while an EU Member State, since fisheries is one of the EU's relatively few exclusive competences. ${ }^{18}$ A select number of these issues and misconceptions are highlighted in what follows. Although certain provisions within it are mentioned, nothing discussed herein turns on whether the Trade and Cooperation Agreement governing the UK-EU post-2020 relationship enters into force so as to dispel the remaining uncertainty, or, as is still theoretically possible at the time of writing, despite initially being provisionally applied, is later abandoned without ever having entered into force.

\section{THE UK AS AN 'INDEPENDENT COASTAL STATE'}

This phrase encapsulates perhaps the most profound way in which the legal landscape has changed. While it is therefore unfortunate that the White Paper repeats it mantralike so often as almost to invite ridicule, ${ }^{19}$ this should not detract from the significance of the change in UK international fisheries policy that the phrase implies. Of the two adjectives, the first is the more likely to mislead. The notion that the UK 'will become'

16. The Fisheries Act (n 4) was initially introduced on 29 January 2020 as the Fisheries Bill HL Bill (2019-21) 71 (2020 Bill) and was eventually enacted on 23 November 2020: UK Parliament, 'Bill Documents - Fisheries Act 2020' (2020) <https://services.parliament.uk/ Bills/2019-21/fisheries/documents.html> accessed 14 February 2021. An earlier Fisheries Bill was introduced in 2018, but its progress stalled in early 2019 amidst the great political uncertainty of that year, and it lapsed with the dissolution of Parliament for the December 2019 general election: Fisheries Bill HC Bill (2017-19) [278] (2018 Bill). The relevant provisions of the Fisheries Act as passed are identical in substance to those of the 2018 Bill, which is accordingly not further mentioned herein, except where necessary to avoid anachronism. Since the minor amendments made to the 2020 Bill during its passage do not affect the matters canvassed, it is the 2020 Bill as originally introduced, reflecting the government's policy intentions and drafting instructions, that is discussed hereinafter as the Bill.

17. See Prime Minister's Office, 'The Queen's Speech 2019' (19 December 2019) $10<$ https:// assets.publishing.service.gov.uk/government/uploads/system/uploads/attachment_data/file/ 853886/Queen_s_Speech_December_2019_-_background_briefing_notes.pdf $>$ accessed 28 December 2020 (Background Notes). For more detail on the 2018 Bill as it then was, see 19-20.

18. Consolidated version of the Treaty on the Functioning of the European Union [2016] OJ C202/1 (TFEU) art 3(1)(d) and (2).

19. The phrase 'independent coastal state' occurs 18 times in all, no fewer than four of these on the first page of the Executive Summary and seven times in the summary of responses to the consultation invited by the government: see respectively White Paper (n 4) 8 and Department for Environment, Food \& Rural Affairs, 'Sustainable Fisheries for Future Generations: Summary of Consultation Responses and Government Response' (2018) <https://assets.publishing.service. gov.uk/government/uploads/system/uploads/attachment_data/file/751309/summary-of-responsesfisheries-for-future-generations.pdf $>$ accessed 9 March 2021. More neutrally, it occurs only twice in the explanatory notes to the 2018 Bill: Explanatory Notes to the Fisheries Bill (Bill 278-EN) 
an independent coastal State ${ }^{20}$ owes more to political messaging than a concern for accuracy; this is what it has at all times been throughout the entire period of modern international law, even if that has been obscured in the fisheries field through the pooling of its decision-making authority with the EU and its predecessors since 1973.

By contrast, the second adjective 'coastal' succinctly serves to draw attention to the fundamental reorientation in the intervening decades of the UK's international fisheries policy stance. Trivially one could say that the UK has always been not just independent but also a coastal State, as is true of all the world's States bar the few dozen that are landlocked, but the phrase denotes something subtly different in the context of the international law of the sea. In legal relationships between the coastal State and any other State(s), the coastal State is the one whose territory generates the maritime zone in which pertinent activity takes place involving ships flagged to the other State(s); by virtue of this proximity it gains regulatory jurisdiction over such ships in that zone. Before 1973, the UK was much nearer the 'distant-water fishing State' end of the spectrum of interests that States pursue in international fisheries, and in the later phase of the 'cod war' with Iceland sought to vindicate those interests in opposition to Iceland's coastal State interests by litigating in the International Court of Justice. ${ }^{21}$ As the White Paper reflects, however, the shrinkage and near-disappearance of its distant-water fishing fleet means that the UK's overall interests will henceforth indeed be best furthered by adopting legal policy positions towards the coastal State end of that spectrum. This may have implications in quota negotiations in the regional fisheries management organisations (RFMOs) that the UK has (re)joined, the next matter considered.

\section{REGIONAL FISHERIES MANAGEMENT BODIES OF POTENTIAL INTEREST TO THE UK}

Post-Brexit, the UK lost any formal link to the RFMOs in which until 31 January 2020 it was represented solely by the EU. This meant that the government had to decide, weighing its fishing interests, of which RFMOs the UK should seek membership in its own right. To avoid a legal hiatus it needed to do so by the end of the transition period on 31 December 2020; until this date the UK remained under the CFP, including the relative stability principle for quotas, ${ }^{22}$ though with fewer rights than if the UK

(Explanatory Notes) paras 4 and 41. The phrase does not appear at all in the Fisheries Act (n 4) itself, though the UK succeeded in inserting one mention of it into the Trade and Cooperation Agreement (n 4) art 494(1).

20. White Paper (n 4) 8.

21. Fisheries Jurisdiction Case (United Kingdom of Great Britain and Northern Ireland v Iceland) (Merits) [1974] ICJ Rep 3. The Court was asked to review the lawfulness of Iceland's 1972 claim to exclusive jurisdiction over fisheries out to 50 nautical miles (nm) from its baseline, which preceded the international consensus on the new institution of a $200 \mathrm{~nm}$ EEZ reached at the Third United Nations Conference on the Law of the Sea. It held that Iceland had some entitlement to preferential rights beyond the $12 \mathrm{~nm}$ limit of exclusive fisheries jurisdiction under international law as it then stood, but not the exclusive rights up to the full $50 \mathrm{~nm}$ claimed, and an obligation to recognise other States' historic fishing rights and in the light of them reach negotiated compromises on access to the preferential area, with equitable apportionment: ibid [79].

22. Withdrawal Agreement (n 5) art 130(4). 
were still a member of the $\mathrm{EU},{ }^{23}$ and was able to attend international negotiations as part of the EU delegation. ${ }^{24}$

As well as Article 130 specific to fisheries, the Withdrawal Agreement governs more generically in Article 129 the transitional relationship vis-à-vis international bodies such as RFMOs regarding the EU's treaty obligations flowing from its membership. Headed 'Specific arrangements relating to the Union's external action', Article 129 of the Withdrawal Agreement reads, in pertinent part:

1. ... During the transition period, the United Kingdom shall be bound by the obligations stemming from the international agreements concluded by the Union ... or by the Union and its Member States acting jointly ... . The Union will notify the other parties to these agreements that during the transition period the United Kingdom is to be treated as a Member State for the purposes of these agreements.

2. During the transition period, representatives of the United Kingdom shall not participate in the work of any bodies set up by international agreements concluded by the Union, ... or by the Union and its Member States acting jointly, unless:

(a) the United Kingdom participates in its own right; or

(b) the Union exceptionally invites the United Kingdom to attend, as part of the Union's delegation, meetings or parts of meetings of such bodies, where the Union considers that the presence of the United Kingdom is necessary and in the interest of the Union, in particular for the effective implementation of those agreements during the transition period; such presence shall only be allowed where Member States participation is permitted under the applicable agreements.

The sole RFMO mentioned in the White Paper is the North-East Atlantic Fisheries Commission (NEAFC), ${ }^{25}$ with which the UK has a long historical association, ${ }^{26}$ but of which it was not at that time a member. In late 2020 the President of NEAFC welcomed the UK's accession to the Convention on Future Multilateral Co-operation in North-East Atlantic Fisheries (1980 Convention). ${ }^{27}$ Previously the homepage of NEAFC featured prominently this statement, dated 17 February 2020:

Following the Agreement on the withdrawal of the United Kingdom of Great Britain and Northern Ireland from the European Union ..., it should be noted that during the transition

23. The rights in essence were limited to being consulted on relevant proposals and developments in the fisheries field, and to have an opportunity to comment on them: ibid art 130(1)-(2). 24. Ibid art 130(3): 'With a view to allowing the United Kingdom to prepare its future membership in relevant international fora, the Union may exceptionally invite the United Kingdom to attend, as part of the Union's delegation, international consultations and negotiations referred to in paragraph 1 of this Article, to the extent allowed for Member States and permitted by the specific forum'.

25. White Paper (n 4) 9, 19.

26. Originally created by the North-East Atlantic Fisheries Convention (signed 24 January 1959, entered into force 27 June 1963) 486 UNTS 157, with the UK as a founding party. It has since been replaced by the Convention on Future Multilateral Co-operation in North-East Atlantic Fisheries (adopted 18 November 1980, entered into force 17 March 1982) 1285 UNTS 129 (1980 Convention). The author was surprised to hear from a former Executive Secretary of NEAFC in 2007 that it, rather than the Public Records Office at Kew, holds a portion of the archives of the former Ministry of Agriculture, Fisheries and Food.

27. North-East Atlantic Fisheries Commission (NEAFC), 'The United Kingdom becomes the 6th Contracting Party to NEAFC' (7 October 2020) <https://www.neafc.org/system/files/UK\% 20accession\%20from\%20Jacques\%20Verborgh.pdf> accessed 14 February 2021. See the 1980 Convention (n 26) art 20(5). 
period, the United Kingdom will be treated as a Member State of the European Union for the purposes of the North-East Atlantic Fisheries Commission.

While this was provided for in the second sentence of Article 129(1) of the Withdrawal Agreement quoted above, as a matter of basic treaty law that provision cannot bind the other parties to the 1980 Convention, ${ }^{28}$ who would have been entitled to treat the UK as a non-member. On the other hand, the very fact of its appearance on the NEAFC website suggests that they had consented to this ${ }^{29}$ no doubt in the expectation, since borne out, that on or before 1 January 2021 the UK would accede to the Convention and become a member in its own right.

The explanatory notes to the 2018 Bill revealed government plans for the UK to join 'a number of' RFMOs, but did not specify which these were. ${ }^{30}$ Guidance thereon was published by the now-defunct Department for Exiting the European Union (DEXEU) in February 2019, listing, apart from NEAFC, four further RFMOs (or their constitutive treaties): the International Commission for the Conservation of Atlantic Tunas (ICCAT), ${ }^{31}$ the Northwest Atlantic Fisheries Organization (NAFO), ${ }^{32}$ the North Atlantic Salmon Conservation Organization (NASCO), ${ }^{33}$ and the Indian Ocean Tuna Commission (IOTC). ${ }^{34}$ Evidently, however, this was done without reference to the legal advisors at the Foreign and Commonwealth Office (as it then was), for not only was the UK already a member in its own right of two of these RFMOs, by virtue of territories outside the $\mathrm{EU},{ }^{35}$ but equally notably the guidance confuses the RFMOs with the treaties establishing them, as well as the steps necessary to become party to these, speaking of 'acced[ing] to a number of these agreements by depositing articles of ratification'. ${ }^{36}$

28. Per the principle pacta tertiis nec nocent nec prosunt, embodied in art 34 of the Vienna Convention on the Law of Treaties (adopted 23 May 1969, entered into force 27 January 1980) 1155 UNTS 331, but also universally regarded as reflecting customary international law: 'A treaty does not create either obligations or rights for a third State without its consent'. The other parties are Denmark (in respect of the Faroe Islands and Greenland), the EU, Iceland, Norway and Russia.

29. Despite the fact that neither the report of the 2019 annual meeting held not long before, nor the EU's opening remarks there, mentioned this matter at all: see respectively NEAFC, '38th Annual Meeting of the North-East Atlantic Fisheries Commission, 12-14 November 2019, Report' $(2019)<$ https://www.neafc.org/system/files/Report_AM-2019_FINAL_plus_List-ofAnnexes_0.pdf $>$ accessed 28 December 2020; and NEAFC, '38th Annual Meeting of the North-East Atlantic Fisheries Commission, 12-15 November 2019, Opening Statement of the European Union' (AM 2019-89, 2019) <https://www.neafc.org/system/files/AM-2019-89_EUOpening-Remarks-2019\%28final\%29.pdf> accessed 28 December 2020.

30. Explanatory Notes (n 19) para 57.

31. Created by the International Convention for the Conservation of Atlantic Tunas (adopted 14 May 1966, entered into force 21 March 1969) 673 UNTS 63 (Rio Convention).

32. Created by the Convention on Future Multilateral Cooperation in the Northwest Atlantic Fisheries (adopted 24 October 1978, entered into force 1 January 1979) 1135 UNTS 369 (Ottawa Convention).

33. Created by the Convention for the Conservation of Salmon in the North Atlantic Ocean (opened for signature 2 March 1982, entered into force 1 October 1983) 1338 UNTS 33.

34. Created by the Agreement for the Establishment of the Indian Ocean Tuna Commission (adopted 25 November 1993, entered into force 27 March 1996) 1927 UNTS 329.

35. The two are ICCAT and the IOTC.

36. See Department for Exiting the European Union, 'Guidance: Fisheries' (5 November 2019) $<$ https://www.gov.uk/government/publications/international-agreements-if-the-uk-leaves-theeu-without-a-deal/fisheries> accessed 28 December 2020 (DEXEU List), where it is stated that the guidance was withdrawn as outdated in May 2020. 
The same document went on to note, this time correctly, that for NEAFC and NASCO 'the assent of existing parties is required. The UK is engaging with the relevant parties in support of UK accession' ${ }^{37}$ It also indicated that the UK would become party to two global fisheries-related treaties concluded under the aegis of the Food and Agriculture Organization of the United Nations (FAO): the Agreement to Promote Compliance with International Conservation and Management Measures by Fishing Vessels on the High Seas (FAO Compliance Agreement) ${ }^{38}$ and the Agreement on Port State Measures to Prevent, Deter and Eliminate Illegal, Unreported and Unregulated Fishing. ${ }^{39}$

As regards NEAFC, Article 20 of the 1980 Convention states:

4. Any state not referred to in paragraph 1 [which the UK is not], except a Member State of the European Economic Community, may accede to this Convention at any time after it has entered into force in accordance with paragraph 2, provided that an application for accession of that State meets with the approval of three-fourths of all the Contracting Parties. An application for accession shall be addressed in writing to the Depositary which shall notify all Contracting Parties thereof. The application is approved if within 90 days from the date of such notification three-fourths of all the Parties in respect of which this Convention has already entered into force by that date have notified the Depositary of their approval of the application. The Depositary shall notify the State applying for accession and all Contracting Parties of the result of the application.

5. Accession shall be effected by the deposit of an instrument of accession with the Depositary and shall take effect on the date of its receipt ...

Article 129(4) of the Withdrawal Agreement provides that 'during the transition period, the United Kingdom may negotiate, sign and ratify international agreements entered into in its own capacity in the areas of exclusive competence of the Union, provided those agreements do not enter into force or apply during the transition period, unless so authorised by the Union'. The UK sought authorisation on 3 April 2020 to become party to the treaties for all five RFMOs listed in the DEXEU guidance, which was granted on 18 September 2020, enabling it to take part in decision-making within these bodies on all matters taking effect in or after 2021 , such as quotas. ${ }^{40}$ Of the two to which it was already party as noted above, this step is explicable for ICCAT, since the UK could not otherwise represent the British Isles and Gibraltar as a coastal State before the transition period's end, but not for the IOTC, as other territories are the basis of its eligibility for membership of the latter.

More broadly, however, quaere whether it was really necessary for the UK to seek the EU's authorisation at all. On a narrow but plausible reading of Article 129(4), the wording 'negotiate, sign and ratify' carries the strong implication that it concerns only new treaties rather than existing ones whose contents are not open to renegotiation by acceding parties such as the UK, but instead must be accepted as they are. Put another way, it

37. Ibid.

38. Agreement to Promote Compliance with International Conservation and Management Measures by Fishing Vessels on the High Seas (adopted 24 November 1993, entered into force 24 April 2003) 2221 UNTS 91 (FAO Compliance Agreement).

39. Agreement on Port State Measures to Prevent, Deter and Eliminate Illegal, Unreported and Unregulated Fishing (adopted 22 November 2009, entered into force 5 June 2016) 55 ILM 1157. 40. Council Implementing Decision (EU) 2020/1305 of 18 September 2020 authorising the United Kingdom to express its consent, in its own capacity, to be bound by certain international agreements to be applied during the transition period in the area of the Union's common fisheries policy [2020] OJ L305/27 recital 6 and art 1. 
can be inferred from the way this provision is drafted that it was meant primarily to regulate free trade agreements that the UK might wish to conclude with other States during the remainder of 2020, which notionally would be negotiated entirely anew even if built on existing templates. These agreements might conceivably satisfy their conditions for entry into force before the transition period expired, but if so, should not become practically operational until 1 January 2021 if the need to seek authorisation for them were to be obviated. In the fisheries field, by contrast, quotas for 2021 would typically be decided by the competent RFMOs before the end of 2020, leaving the EU in a conflicted position if it were still negotiating these on the UK's behalf. Hence it was vital for the UK to take the requisite treaty action to achieve membership of them in time to negotiate quotas in its own interest, and not obvious what reason the EU could have for seeking to prevent this without risking accusations of bad faith.

As mentioned, the UK's membership of NEAFC took effect on 7 October 2020, the same day that the UK lodged its application to accede to the 1980 Convention, ${ }^{41}$ which suggests that the approval must have been prenegotiated, although the report of NEAFC's annual meeting for 2020 offers no clue as to the process by which this came about. In theory the application could have failed to gain the support of three quarters of NEAFC's membership if only three or fewer of the then five parties had notified the depositary of their approval, but this would have been an extraordinary turn of events had it occurred, for the UK is a coastal State of the Northeast Atlantic, and one that could not credibly be argued to lack a 'real interest' in the fisheries of that part of the ocean so as to justify its exclusion under Article 8(3) of the UN Fish Stocks Agreement (UNFSA). ${ }^{42}$ Moreover the UK is the depositary of the 1980 Convention per its Article 22, and NEAFC's headquarters are located in London.

The position is not markedly different in respect of NASCO, except that until 2020 the UK had never in its own right been a member of it, despite its headquarters being in Edinburgh. ${ }^{43}$ It was not among the initial eligible signatories of the founding Convention for the Conservation of Salmon in the North Atlantic Ocean enumerated in Article 17(1) of the latter, but Brexit has given the UK this opportunity for the first time, as paragraph 3 of the same Article opens the Convention to accession 'subject to the approval of the Council, by any other State that exercises fisheries jurisdiction in the North Atlantic Ocean or is a State of origin for salmon stocks subject to this

\section{NEAFC (n 27).}

42. Art 8(3) and (4) of the Agreement for the Implementation of the Provisions of the United Nations Convention on the Law of the Sea of 10 December 1982 Relating to the Conservation and Management of Straddling Fish Stocks and Highly Migratory Fish Stocks (adopted 4 August 1995, opened for signature 4 December 1995) 2167 UNTS 3 (UNFSA), to which all NEAFC members are party, requires RFMOs to be open to States with a 'real interest' in the fisheries they manage, implying that they must leave unexercised any power under their constitutive treaty to veto any such State's entry. Since 2003 the UK has been party to the UNFSA both in its own right in respect of all its overseas territories, and also, until Brexit formally, and possibly in practice until the end of the transitional period, as an EU Member State. It had previously ratified the UNFSA in 1999, but only in respect of certain overseas territories outside the EU: see United Nations Treaty Collection, ' 7 . Agreement for the Implementation of the Provisions of the United Nations Convention on the Law of the Sea of 10 December 1982 Relating to the Conservation and Management of Straddling Fish Stocks and Highly Migratory Fish Stocks' fn $6<$ https://treaties.un.org/Pages/ ViewDetails.aspx ?src=TREATY\&mtdsg_no=XXI-7\&chapter $=21 \&$ clang $=$ en $>$ accessed 28 December 2020.

43. See North Atlantic Salmon Conservation Organization (NASCO), 'Contact Us' <http:// www.nasco.int/contactus.html> accessed 28 December 2020. 
Convention'. The UK fits this description, as was recognised in a decision of the Council following the Secretariat's circulation earlier in 2020 of a paper canvassing views of the then six parties on the course of action proposed by the UK in the light of the Withdrawal Agreement. A startling revelation in this paper is that, as early as February 2019, the UK had approached NASCO, seeking its Council's approval to accede, though only in the contingency that the UK left the EU in the absence of a withdrawal agreement, hence the request was repeated unqualified in July $2020 .^{44}$ The decision was postponed until the Council of the EU had adopted its authorising decision on the UK's aforementioned application. ${ }^{45}$ The UK eventually deposited its instrument of accession on 27 November $2020 .{ }^{46}$ Despite the theoretical possibility of a veto of its entry by NASCO's Council, it was not in the existing members' interest to allow the UK to emerge as a State not subject to the obligations of membership, which would expose salmon spawned in their own rivers, and passing through the UK's EEZ on their migratory path to and from the Atlantic Ocean, to being caught there by UK-licensed vessels. More surprising, given its thoroughness in other respects, is that the Secretariat circular simply accepts unquestioningly the situation laid out in Articles 129 and 130 of the Withdrawal Agreement, rather than asking the existing members whether that would be an acceptable way to proceed. If those proprieties were not observed, it may simply be because the other members were relieved at the prospect of a seamless transition in the UK's status to shield them from exposure to the turmoil engulfing many other aspects of the Brexit negotiations, and cared little for the attendant legal niceties.

The UK has never been a member of NAFO, but was among the founding States of its predecessor, the International Commission for the Northwest Atlantic Fisheries. ${ }^{47}$ As any State can accede to the Ottawa Convention, ${ }^{48}$ the UK faced no obstacle in doing so on 18 September $2020 .{ }^{49}$

Apart from NEAFC, NASCO and NAFO, the EU holds membership of many other RFMOs in which it participates to the exclusion of its Member States. Unusually, in the remaining two listed by DEXEU, the UK was in fact already a member, eligible to join by virtue of having territory outside the EU in the relevant part of the world; that

44. NASCO, 'Report of the September 2020 Inter-Sessional Meeting of the Council of the North Atlantic Salmon Conservation Organisation' (CNL(20)56, 9-11 September 2020) para 4 and annex 6 (the letter to the Depositary from the UK Parliamentary Under-Secretary of State of the Department for Environment, Food and Rural Affairs, Victoria Prentis MP) $<$ https://nasco.int/wp-content/uploads/2020/10/CNL2056_Report-of-the-September-2020-InterSessional-Meeting-of-the-Council-of-the-North-Atlantic-Salmon-Conservation-Organization. docx.pdf> accessed 28 December 2020. The other six members are Canada, Denmark in right of the Faroe Islands and Greenland, the EU, Norway, Russia and the United States. There is no mention of the 2019 request in the report of that year's annual meeting, nor in the equivalent reports of a parallel request to any other of the RFMOs the UK has since (re)joined.

45. Ibid para 4.8.

46. See NASCO, 'The United Kingdom Becomes the Seventh Contracting Party to NASCO' (27 November 2020) <https://www.nasco.int/the-united-kingdom-becomes-theseventh-contracting-party-to-nasco/> accessed 28 December 2020.

47. See Northwest Atlantic Fisheries Organization, 'International Commission for the Northwest Atlantic Fisheries (ICNAF) <https://www.nafo.int/About-us/History/internationalcommission-for-the-northwest-atlantic-fisheries-icnaf> accessed 28 December 2020.

48. Ottawa Convention (n 32) art XXII(4).

49. See Northwest Atlantic Fisheries Organization, 'Governance' <https://www.nafo.int/ Home/NAFO-Governance> accessed 14 February 2021. 
is, as a coastal State. These are ICCAT, thanks to certain of its island territories (Ascension Island, Bermuda, the British Virgin Islands, Saint Helena and Tristan da Cunha and the Turks and Caicos Islands), and the IOTC on the strength of the British Indian Ocean Territory, though the latter may not be a long-term proposition. ${ }^{50}$ As a claimant to territory in Antarctica as well as the sub-Antarctic islands (the Falklands, South Georgia and the South Sandwich Islands) the UK is also a member of the Commission for the Conservation of Antarctic Marine Living Resources (CCAMLR) ${ }^{51}$ not mentioned in the DEXEU guidance.

Only the first of these required action as a consequence of Brexit: despite already being an ICCAT member, the UK notified the depositary of the Rio Convention on 21 October 2020 that it would be party also in respect of the British Isles and Gibraltar. ${ }^{52}$ Although no announcement to this effect was made, the ICCAT website's membership page offered an initial clue that this had occurred. ${ }^{53}$ At all events, the renewed presence of Atlantic bluefin tuna in British waters ${ }^{54}$ will give the UK a

50. This territory is wholly claimed by Mauritius and was the subject of an advisory opinion rendered by the International Court of Justice on the consequences of its separation from Mauritius as the UK's price for granting independence to that State: Legal Consequences of the Separation of the Chagos Archipelago from Mauritius in 1965 (Advisory Opinion) [2019] ICJ Rep 95. The UK has not taken any steps to date to conform to the finding that the process of decolonization of Mauritius was not lawfully completed when that country acceded to independence in 1968, following the separation of the Chagos Archipelago' and that the UK is 'oblig[ed] to bring to an end its administration of the Chagos Archipelago as rapidly as possible': see respectively [183(3)] and [183(4)]. Mauritius takes the view that the UK is not entitled to IOTC membership and in March 2020 asked that an item titled 'Termination of United Kingdom's Membership in the IOTC as a Coastal State' be included in the agenda of the 2020 annual meeting, but accepted its postponement to the 2021 annual meeting as a consequence of the coronavirus pandemic: IOTC, 'Report of the 24th Session of the Indian Ocean Tuna Commission' (IOTC-2020-S24R[E], 2-6 November 2020) 29 <https://iotc.org/sites/default/files/documents/2020/12/IOTC2020-S24-RE.pdf> accessed 28 December 2020.

51. Created by the Convention on the Conservation of Antarctic Marine Living Resources (adopted 20 May 1980, entered into force 7 April 1982) 1329 UNTS 47.

52. By listing the territories, the depositary's circular letter $<$ http://www.fao.org/treaties/results/ details/en/c/TRE-000252/> accessed 7 April 2021 obscures this point, but even so makes it clear that this notification superseded the previous instrument deposited by the UK under the Rio Convention (n 31) on 10 November 1995, which had already been varied when the then European Community gained membership of ICCAT on 1 January 1998; by operation of art XIV(6), the UK had ceased to be a member except in respect of its overseas territories: see Food and Agriculture Organization of the United Nations, 'International Convention for the Conservation of Atlantic Tunas' <http://extwprlegs1.fao.org/cgi-bin/treaty.exe?rec_id=000031\& database $=$ tre $\&$ search_type $=$ link \& table $=$ link\&lang=eng \&format_name $=@ E F A L L>$ accessed 14 February 2021. Neither state of affairs is precluded by art 29 of the Vienna Convention on the Law of Treaties ( $n$ 28): 'Unless a different intention ... is otherwise established [as is the case here], a treaty is binding upon each party in respect of its entire territory'.

53. See International Commission for the Conservation of Atlantic Tunas, 'Contracting Parties' <https://iccat.int/en/contracting.html\#> accessed 28 December 2020, where the UK's flag appears at the bottom of the chronological list above the date of 21 October 2020, misleadingly implying that it became ICCAT's newest member that day; there was no press release, doubtless because it is accepted on all sides that the UK has never relinquished its membership. 54. See Matt McGrath, 'Warming Seas Linked to Bluefin Tuna Surge in UK Waters', BBC News (London, 2 January 2019) <www.bbc.co.uk/news/science-environment-46738175> accessed 28 December 2020. 
case for a quota as a coastal State under ICCAT's allocation guidelines; ${ }^{.5}$ this is not incompatible with the current prohibition on fishing for this stock in the UK EEZ, which assists its rebuilding, although it could make other members, obliged to restrict their own catches, reluctant to grant the UK a quota that its stated intention is not to use. To overcome this, it may be necessary for the UK to affirm that, once a given stock recovery threshold is reached, it will use the quota for fishing.

There are several other RFMOs whose membership would be open to the UK via the same territorial qualification route, including island possessions in the Pacific Ocean ${ }^{56}$ and others already mentioned in the Atlantic and Indian oceans, ${ }^{57}$ but as its EU membership never barred the UK from joining these, there is no reason to expect that Brexit will act as a spur to this. The same goes for the General Fisheries Commission for the Mediterranean, ${ }^{58}$ of which the UK was an original member until it withdrew in 1968. The EU's membership of this body is under mixed competence and several EU Member States are members alongside it, ${ }^{59}$ so it may be doubted whether the fact that Gibraltar has left the EU as part of the UK will of itself prompt the UK to rejoin, something it could already have done had it wished. In the longer term, however, it is not ruled out that the UK may at some point wish to act on these possibilities as it reassesses its international fishing interests in respect of territory outside the British Isles.

55. International Commission for the Conservation of Atlantic Tunas, 'Compendium: Management Recommendations and Resolutions Adopted by ICCAT for the Conservation of Atlantic Tunas and Tuna-Like Species' (2020) <https://www.iccat.int/Documents/Recs/ COMPENDIUM_ACTIVE_ENG.pdf> accessed 28 December 2020.

56. Pitcairn, Henderson, Ducie and Oeno Islands, falling within the areas managed by the Western and Central Pacific Fisheries Commission (WCPFC), the Inter-American Tropical Tuna Commission and the South Pacific Regional Fisheries Management Organisation, created respectively by: the Convention on the Conservation and Management of Highly Migratory Fish Stocks in the Western and Central Pacific Ocean (adopted 5 September 2000, entered into force 19 June 2004) 2275 UNTS 43; the Convention Between the United States of America and the Republic of Costa Rica for the Establishment of an Inter-American Tropical Tuna Commission (adopted 31 May 1949, entered into force 3 March 1950) 80 UNTS 3 (since superseded by the Convention for the Strengthening of the Inter-American Tropical Tuna Commission Established by the 1949 Convention Between the United States of America and the Republic of Costa Rica, Antigua (adopted 27 June 2003, entered into force 27 August 2010)); and the Convention on the Conservation and Management of the High Seas Fishery Resources of the South Pacific Ocean (adopted 14 November 2009, entered into force 24 August 2012) 2899 UNTS 211.

57. This applies to the South-East Atlantic Fisheries Organisation, created by the Convention on the Conservation and Management of Fishery Resources in the South East Atlantic Ocean (adopted 20 April 2001, entered into force 13 April 2003) 2221 UNTS 189, and the Southern Indian Ocean Fisheries Agreement (adopted 7 July 2006, entered into force 21 June 2012) 2835 UNTS 409, which creates no RFMO but serves as a vehicle for managing internationally the fisheries concerned. The Mauritian territorial claim and the International Court of Justice's 2019 Advisory Opinion (n 50) may make the UK hesitate regarding becoming party to the latter agreement.

58. Originally created under a different name by the Agreement for the Establishment of a General Fisheries Council for the Mediterranean (adopted 24 September 1949, entered into force 20 February 1952) 126 UNTS 237, the change from Council to Commission being one of several amendments effected since then.

59. See European Union External Action Service, 'Summary of Treaty: Agreement Establishing the General Fisheries Commission for the Mediterranean (GFCM)' $<$ http://ec. europa.eu/world/agreements/prepareCreateTreatiesWorkspace/treatiesGeneralData.do? step $=0 \&$ redirect=true \& treatyId=471 $>$ accessed 28 December 2020, 'Remarks', 'Competence' and 'Contracting Parties'. 
As a new or returning member of these RFMOs, negotiating within them its share of catch or effort quotas independently of the EU might not be without problems for the UK, given that these bodies tend to be reluctant to allocate shares to new participants. ${ }^{60}$ Uncertain at this point is whether the UK's interests from the perspective of maximising its share of the allocated quotas lie more in stressing (a) the continuity with any existing or previous UK membership of the RFMO and the catch history before and during its EU membership, or (b) the fact that a given stock resides in or migrates through UK waters. Only in the very short term is this problem avoided for a few stocks managed by ICCAT and NAFO, where an agreed division of what by implication was the EU quota for 2021, settled earlier in 2020, is set out in Tables C and D of Annex 36 of the Trade and Cooperation Agreement. Each of the $\mathrm{UK}$ and EU is required to notify these RFMOs of its respective shares, any subsequent changes being 'a matter for the relevant multilateral fora' ${ }^{61}$

For every other stock managed by any RFMO, however, the EU will no doubt maintain that quotas were awarded to it in its own right and should hence continue unaffected by the departure of one Member State. This would directly contradict any UK claim of entitlement to succeed to some portion of the EU quota commensurate with the scale of its recent participation in the fisheries, to the extent that it has not been brought to account in Annex 36 of the Trade and Cooperation Agreement. For such an argument to have any chance of persuading its fellow members, it would require the UK to adopt a firmer stance in favour of the property-like nature of such quota than most States have hitherto been prepared to embrace. The signs of this are not promising, as the Fisheries Act retains the somewhat mealy-mouthed EU terminology describing catch and effort quotas as 'fishing opportunities' ${ }^{62}$ The alternative would be to rely on Articles 8 and 11 of the UNFSA, ${ }^{63}$ though this is not an option in NASCO as salmon stocks are outside its purview, governed as anadromous species by Article 66 of the United Nations Convention on the Law of the Sea ${ }^{64}$ (UNCLOS) rather than Articles 63(2) or 64 to which the UNFSA is tied. Whichever of

60. In 2003, NEAFC went so far as to adopt 'Guidelines for the Expectation of Future New Contracting Parties with Regard to Fishing Opportunities in the NEAFC Regulatory Area', warning potential new entrants not to expect any quota of stocks already allocated: NEAFC, 'Becoming a Contracting Party' <https://www.neafc.org/becomingacp > accessed 28 December 2020 (NEAFC Guidelines).

61. Trade and Cooperation Agreement (n 4) art 505(2)-(3).

62. Fisheries Act (n 4) ss 23-27. See also the Explanatory Notes (n 19) para 131 which, consistently with s 23(1) of the Fisheries Act, defines 'fishing opportunities' as 'refer[ring] to the maximum amount of fish that may be caught and the maximum number of days that may be spent at sea' but contains no hint of any proprietary character.

63. UNFSA (n 42). Entry to NEAFC, as demonstrated above, is not automatic, while WCPFC is even more stringent in requiring the concurrence of every existing member to the admission of a new one. Denial by any RFMO the UK may wish to join that it has a real interest in the sense of art 8(3) of the UNFSA would be counterproductive, however, tantamount to a refusal to cooperate with the UK and making it impossible for the RFMO to insist on cooperation with it by a UK involuntarily excluded from participation in its affairs. Art 11 of the UNFSA is a non-exhaustive list of factors for RFMOs to take into account in determining new entrants' participatory rights in their fisheries, with which the blanket statement of the NEAFC Guidelines (n 60) is hard to reconcile.

64. United Nations Convention on the Law of the Sea (adopted 10 December 1982, entered into force 16 November 1994) 1833 UNTS 3 (UNCLOS). 
the two it is, the UK should adopt a consistent position so that its statements in one RFMO cannot be controverted by other members pointing to incompatible utterances it has made in another.

In several RFMOs in which the UK formerly represented only its island possessions because the EU is also a member, however, a practical difference is likely to be felt immediately: UK delegations can expect to enjoy greater freedom of action than has been the case until now, as the pressure to align themselves with EU positions becomes less overwhelming. ${ }^{65}$

\section{MAXIMUM SUSTAINABLE YIELD AND CATCH LIMITS}

The White Paper presents the maximum sustainable yield (MSY) concept in an oversimplified manner that casts doubt on whether it has been properly understood, which in turn may lead to the UK failing to comply with its international obligations in this regard. Under UNCLOS, States must take measures that maintain or restore the biomass of fish stocks to levels producing the MSY $\left(B_{M S Y}\right)$, taking into account economic and environmental factors together with recommended international standards, ${ }^{66}$ but this is far from being the same thing as aiming to catch the MSY itself, with which it appears to have been confused in parts of the White Paper, such as its reference to 'achievement of MSY' as a policy goal championed by the UK. ${ }^{67}$ There is, if not a flat contradiction between two successive sentences, then at best a dangerous ambiguity: one speaking of 31 stocks 'now being exploited in line with MSY', while the other avers that the 'process of rebuilding stocks to their maximum potential is a gradual one, but it is bearing results' ${ }^{68}$ Are the 31 stocks already today being exploited at MSY, or rather at levels consistent with rebuilding to $B_{M S Y}$ within a set timeframe, so eventually allowing the MSY to be taken? A footnote refers to a written answer by the Secretary of State to a Parliamentary question, but the same ambiguity is encountered there, as it speaks merely of an 'MSY rate' ${ }^{69}$ Elsewhere, more reassuringly orthodox statements are found, such as a goal to see 'all fish stocks ... recovered to and maintained at levels that can produce their maximum sustainable yield' ${ }^{70}$

The distinction is significant because, for overfished stocks whose biomass is below $B_{M S Y}$, catching the full MSY will inevitably deplete the stock further, not rebuild it; only after the rebuilding is achieved can the MSY be taken, and achieving it requires catch to be held below MSY for as long as that takes. The faster the desired rebuild, the

65. Art 129(3) of the Withdrawal Agreement (n 5) reflects this: 'In accordance with the principle of sincere cooperation, the United Kingdom shall refrain, during the transition period, from any action or initiative which is likely to be prejudicial to the Union's interests, in particular in the framework of any international organisation, agency, conference or forum of which the United Kingdom is a party in its own right'.

66. UNCLOS (n 64) arts 61(3) (in relation to the EEZ) and 119(1)(a) (in relation to the high seas).

67. White Paper (n 4) 24.

68. Ibid. See also 10 ('promote fishing within MSY ranges' in mixed-species fisheries).

69. See UK Parliament, 'Fisheries: Question for Department for Environment, Food and Rural Affairs' (UIN 121754, 9 January 2018) <www.parliament.uk/business/publications/writtenquestions-answers-statements/written-question/Commons/2018-01-09/121754> accessed 28 December 2020.

70. White Paper (n 4) 25. 
lower the catch that can be taken without jeopardising it. There is a welcome acknowledgement that 'achieving MSY may involve short term costs ... from a reduction in catch for certain species, but results in longer term benefits from a more sustainable level of fishing'. ${ }^{71}$ But the confusion is compounded when the White Paper refers to 'set[ting] rates that will optimise MSY across the different stocks' of a multispecies fishery ${ }^{72}$ something that is either meaningless or impossible, as MSY can be calculated only stock by stock. In multispecies fisheries, every stock has its own MSY, but the fleet cannot catch all of them at once, as it will inevitably reach the MSY of some stock first, and will then exceed it if fishing continues in an attempt to reach that of others; long-term sustainability instead dictates a total catch limit somewhere below the sum of all the separate MSYs. These extracts are evidence that, while the above points were not lost on the departmental technical advisers, they did not succeed in explaining them fully to policy-makers, who are after all the ones facing industry pressures to allow higher catches and may lack the necessary understanding to resist them.

At the Committee stage in the House of Lords, the MSY concept was subjected to trenchant criticism reflecting the broad scientific consensus on its numerous inadequacies. ${ }^{73}$ Lord Gardiner, Parliamentary Under-Secretary of State for Rural Affairs and Biosecurity, defended the place of MSY in the 2020 Bill as the 'recognised international standard' ${ }^{74}$ but that too is an outmoded oversimplification. This is because, for straddling and highly migratory stocks (those present both in one or more States' EEZs and the high seas), the UNFSA, reinforcing the UNCLOS obligations in this respect, calls for more conservative targets and makes a subtle but vital change to the standard by redefining the MSY reference points such as $B_{M S Y}$ and $F_{M S Y}{ }^{75}$ as limits; these may not be exceeded and States must take pre-agreed restorative action if the limit is breached. ${ }^{76}$ Admittedly, the UNFSA is not directly applicable by its own terms to most of the UK's international fisheries, as the UK's EEZ largely abuts neighbouring EEZs rather than the high seas. Yet both the UK and all its neighbours are party to the UNFSA, which also imposes an obligation on relevant States to ensure compatibility between EEZ and high seas management measures for the same stock. ${ }^{77}$ Indirectly, therefore, even in transboundary fisheries not strictly subject to the UNFSA, it is not just superior fisheries conservation policy to comply with it nonetheless, but also superior legal policy, as it will assist to avoid legal problems arising from the pursuit of UNCLOS standards in some such fisheries but UNFSA ones in others.

Now that it has left the EU, the UK will need to set allowable catches in its EEZ with reference to the $B_{M S Y}$ as directed by Article 61(1) of UNCLOS, extending to shared stocks under Article 63(1); that is, those present also in neighbouring EEZs. But it faces a dilemma regarding the management of these shared stocks, since the Trade and Cooperation Agreement envisages a joint procedure with the EU for setting the allowable catch of numerous stocks: ${ }^{78}$ if it adopts the UNFSA-enshrined

71. Ibid 24.

72. Ibid.

73. HL Deb 9 March 2020, vol 802, cols 838-839 (Lord Krebs).

74. Ibid col 881 .

75. $F_{M S Y}$ is the level of fishing effort that generates the MSY when applied to a stock of size $B_{M S Y}$.

76. UNFSA (n 42) annex II.

77. Ibid art 7 .

78. Trade and Cooperation Agreement (n 4) arts 498 and 499. 
precautionary approach to fisheries by setting MSY reference points as limits, ${ }^{79}$ it may make agreement with the EU harder to achieve, since the latter has not moved beyond the UNCLOS approach, whereby those points are targets. ${ }^{80}$ The question will in practice turn on the relative appetites of the UK and EU for risk in terms of how much fishing pressure, and thus danger of collapse, each is prepared to put on stocks. Overly broad references in the White Paper simply to 'MSY' are unhelpful in this regard, as they mostly blur this looming dilemma and make it more difficult to resolve once it emerges into the open. For the reason already given, it is unclear whether what the EU describes as precautionary management, by which it appears to regard it as sufficient to limit catches to the full MSY irrespective of stock size, meets the UNCLOS standard of rebuilding smaller stocks to $B_{M S Y}$, let alone the more stringent standard of the UNFSA applicable to straddling and highly migratory stocks. ${ }^{81}$ Maximising long-term yields in these circumstances will require lower catches in the short term, which may create political friction both within the UK and between the UK and the EU, with UK fishing industry interests, desiring quick post-Brexit gains, unlikely to welcome measures aimed at restoring stocks to $B_{M S Y}$ by setting low catch limits in UK waters if they have been led instead to expect that they would be able to catch the full MSY. ${ }^{82}$ A hopeful sign, though no more than that in view of the contradictory statements made elsewhere, is that in the Trade and Cooperation Agreement the UK and EU have settled on a formula that does at least reproduce faithfully the UNCLOS standard, albeit as a shared objective rather than an outright obligation to guide their future actions, ${ }^{83}$ and consequently giving little ground for optimism that they will be prepared to use the preferable UNFSA one.

It is thus in the UK's economic as well as environmental interest to ensure that scientific advice is not disregarded for political reasons in setting catch limits and managing fisheries once it is free to do so. In short, if the UK regards the fisheries management currently pursued under the CFP as insufficiently precautionary, Brexit offers a good opportunity to move towards remedying this. If on the other hand the UK regards the CFP as excessively precautionary, there is some scope after Brexit to escape its restraints, but only by moving further away from compliance with the UNCLOS requirement to restore stocks to, or maintain them at, $B_{M S Y}$.

79. The requirement is mandatory under art 6 of the UNFSA (n 42) for straddling and highly migratory stocks, but that instrument does not cover shared stocks, the bulk of those affected by Brexit.

80. Tellingly, the latest (2013) reform of the Common Fisheries Policy included 'a commitment to fish at maximum sustainable yield': Explanatory Notes (n 19) para 17. This is reinforced by the definition of the term 'precautionary approach to fisheries management' in art FISH.2(j) of the March Draft Text (n 10), which is appreciably simpler and less demanding than that set out in annex II to the UNFSA, and has survived with minimal change into art 495(1)(b) of the Trade and Cooperation Agreement (n 4).

81. The same is true of restricting fishing effort to $F_{M S Y}$, which results in smaller catches that slow (but do not stop or reverse) further decline and are not low enough to allow any rebuilding. 82. In the same interest of avoiding confusion, it would have been better to avoid referring to 'sustainable management' of fish stocks, as the White Paper does several times (see (n 4) 8, 9, $10,15,19,20,24,27,34,38$ and 42 ), as this phrase misdescribes the goal; directly it is catches from the stocks, and indirectly the fisheries pursuing them, that need to be sustained, not the management structures.

83. Trade and Cooperation Agreement (n 4) art 494(2). 


\section{PREVENTING ILLEGAL, UNREPORTED AND UNREGULATED FISHING}

Few would gainsay that the UK should do what it can to combat illegal fishing in its and other States' waters, as well as unreported fishing inasmuch as this is not illegal, since proper management of stocks requires the scientists advising managers to know as accurately as possible how much of each species is caught, where and with what gear and input of fishing effort. Regrettably, however, the White Paper misses the opportunity to prise loose from these the separate concept of unregulated fishing, a different kind of problem. ${ }^{84}$ An international trend in this direction may have started with the 2018 Agreement to Prevent Unregulated High Seas Fisheries in the Central Arctic Ocean, ${ }^{85}$ clearly aimed solely at ensuring that no unregulated fishing takes place, by providing for its parties to agree on regulation of the fisheries before they begin. This rational approach the UK would do well to emulate. The solution to unregulated fishing is to regulate it (so that infringements of the regulations can then be treated as truly illegal), not to pretend that it is no different from illegal fishing, as the EU has done in an egregious manner for over a decade through the relevant EU regulation, ${ }^{86}$ whose substance continues in force for the time being under the European Union (Withdrawal) Act 2018. When it comes time for the UK to adopt its own replacement legislation, it should seize the opportunity to end the conflation rather than perpetuate it, as did first the EU draft treaty text ${ }^{87}$ and now the Trade and Cooperation Agreement, whose level-playing-field provisions regarding environmental policy include a commitment to 'adopt and maintain their respective effective tools to combat IUU [illegal, unreported and unregulated] fishing, including measures to exclude the products of IUU fishing from trade flows, and cooperate to that end' ${ }^{88}$ This formulation may leave enough room for the UK to assert the common-sense proposition that within both parties' waters there is by definition no unregulated fishing, and to decline to ban importation of fish caught in unregulated fisheries elsewhere if it chooses to prefer the interests of its consumers, even if it is realistic to expect that it cannot be re-exported to the EU. The omens are not easily read as to how probable this is: no need exists for the Fisheries Act to take a position on the matter, and the phrase is absent altogether from it, making a single appearance only in the explanatory notes. ${ }^{89}$

84. See White Paper (n 4) 29.

85. Agreement to Prevent Unregulated High Seas Fisheries in the Central Arctic Ocean (adopted 3 October 2018, not yet in force). For the text of this Agreement, see Government of Canada, 'Agreement to Prevent Unregulated High Seas Fisheries in the Central Arctic Ocean' $<$ https://www.dfo-mpo.gc.ca/international/agreement-accord-eng.htm> accessed 9 March 2021. Absent from the DEXEU List (n 36), it is not clear whether, post-Brexit, the UK will wish to become party to this agreement alongside the EU which helped negotiate it, or why no attempt was made in the text of the agreement to Brexit-proof it.

86. Council Regulation (EC) No 1005/2008 of 29 September 2008 establishing a Community system to prevent, deter and eliminate illegal, unreported and unregulated fishing [2008] OJ L286/1. See also Commission Regulation (EC) No 1010/2009 of 22 October 2009 laying down detailed rules for the implementation of Council Regulation (EC) No 1005/2008 [2009] OJ L280/5; and generally Andrew Serdy, 'Pacta Tertiis and Regional Fisheries Management Mechanisms: The IUU Fishing Concept as an Illegitimate Short-Cut to a Legitimate Goal' (2017) 48 Ocean Development \& International Law 345.

87. March Draft Text (n 10) art LPFS.2.45.

88. Trade and Cooperation Agreement (n 4) art 404(2)(c).

89. Explanatory Notes (n 19) para 22. 


\section{SECONDARY REGULATION}

The White Paper sensibly proposes that catch and effort limits be set by secondary legislation. ${ }^{90}$ With the lifecycles of most fish, even longer-lived species, displaying strongly annual cyclical elements, particularly their migrations, so too inevitably do the fisheries targeting them. The consequent need to react promptly to rapidly evolving circumstances makes primary legislation impracticable at the level of detail needed for managing individual stocks and fisheries, though there is undoubtedly a role for it on broader questions. ${ }^{91}$ In this context, however, it is unclear why days at sea is the only input deemed suitable as a basis for measuring fishing effort; many other yardsticks of effort are conceivable and, even if considered less useful or appropriate, it would not be wise to preclude a priori all but one of them as the White Paper foreshadowed for the 2018 Bill ${ }^{92}$ and subsequently the Fisheries Act does. ${ }^{93}$ It can still serve a purpose to have them in managers' armoury even if rarely or never used. Their absence is all the more remarkable in light of the provision in the Trade and Cooperation Agreement envisaging an unrestricted range of ways to restrain effort as the potential subject of discussion at the parties' annual consultations. ${ }^{94}$ It will make it more difficult for the UK to comply with RFMO measures that restrict fishing effort calculated in other ways, or more likely will simply lead to the non-adoption of such measures in the first place, where the RFMO's decision-making procedure allows single members such as the UK to veto them; managing stocks shared with the EU and the UK's other neighbours will similarly be subjected to needless constraints and delays if the UK must now resort to primary legislation to enact other kinds of effort limits.

\section{THE MARINE MANAGEMENT ORGANISATION AND COST RECOVERY}

The cost-recovery policy canvassed in the White Paper is suboptimal as legal policy. ${ }^{95}$ That document rightly notes several times that fish stocks are public assets, ${ }^{96}$ but it does not follow from this that the fishing industry should bear the costs to the government of running the Marine Management Organisation (MMO), no more and no less. While the Fisheries Act has not itself made any pertinent changes, the subjection of any economic activity to regulation by the MMO or another public body primarily safeguards the public interest, any benefit to the industry regulated being secondary. This suggests that it is the public purse that should bear the management costs and, instead, a surtax of some kind should be imposed on quota-holders, reflecting the reality that quota by its nature entitles them to catch and profit from public asset fish stocks, opportunities denied to all other persons. A further reason for preferring this to cost-recovery levies hypothecated specifically to financing the operations of the $\mathrm{MMO}$ is that the latter create a perverse incentive for industry lobbying to minimise

90. White Paper (n 4) 11, 14, 15 and 17.

91. Ibid. See also 16.

92. Ibid. See also 25.

93. Fisheries Act (n 4) s 23(1)(b). The only other input control mentioned in the Explanatory Notes (n 19) para 41, for which authority continues unaffected by the Act, is the Sea Fish (Conservation) Act 1967 (UK), providing in s 3(1) for the prescription of minimum mesh size of nets.

94. Trade and Cooperation Agreement (n 4) art 498(4)(d).

95. White Paper (n 4) 17 and 36.

96. Ibid. See also 15, 26 and 33. 
the MMO's regulatory activity irrespective of the fisheries' actual needs at any given time. Whether the revenue raised by taxation should exceed or fall short of covering the MMO's costs is a non-legal question on which econometric advice should be sought; the answer may vary from year to year independently of fluctuations in those costs.

\section{A PROBLEM SOLVED BY POSTPONEMENT: LATE DENUNCIATION OF THE 1964 LONDON CONVENTION}

An incidental but unequivocally beneficial effect of the second postponement of the Brexit date was to prevent a seemingly unplanned and embarrassing survival of one element of the old order for over three months beyond 29 March 2019 had the UK's withdrawal occurred on that day. For reasons never explained, rather than taking this step simultaneously with the notification under Article 50 of the TEU, to align the notice periods, it was not until 3 July 2017 that the UK gave the requisite two years' notice of its withdrawal from the 1964 London Fisheries Convention (1964 Convention). ${ }^{97}$ This produced the only situation in which it would have made a difference whether the CFP's binding effect for the UK ended on 29 March 2019 or, as ultimately happened, lasted through the whole of 2020 under the Withdrawal Agreement. For, in the former case, until 3 July 2019 the UK would nonetheless have remained obliged to permit access to vessels from Belgium, France, Germany, Ireland and the Netherlands to fisheries in the belt of water between 6 and $12 \mathrm{~nm}$ from the UK's territorial sea baseline, ${ }^{98}$ an effect that was masked with the CFP still in force to the end of 2020. Clause 7 of the 2018 Bill made no allowance for this, revoking in toto not only Article 5 of the CFP regulation guaranteeing equal access to the UK EEZ to vessels flagged to other Member States, but also Annex I mirroring the special rights under the 1964 Convention. ${ }^{99}$ Presumably, however, although the drafting could be clearer, access of those five States' vessels for the remainder of the notice period would have been a 'purpose recognised ... by any international agreement or arrangement to which the United Kingdom is a party' and thus exempted them from the prohibition of subclause $8(1)^{100}$ on entering (and fishing in) the EEZ.

As the 1964 Convention dates from a period when the concept of the EEZ was yet unknown to international law, the better view is that the obligation thereunder does not in fact extend to the UK's EEZ, despite the anomalous outcome that vessels of the five States concerned would have benefited in this short putative interregnum from greater rights in an area of plenary UK sovereignty than they have in the waters beyond where the UK has lesser sovereign rights: to explore and exploit, conserve and manage the resources. ${ }^{101}$ There is room for doubt, however, whether the UK would have adopted or acted on this view, as it has taken the opposite stance in the dispute over the parallel

97. Fisheries Convention (adopted 9 March 1964, entered into force 15 March 1966) 581 UNTS 57, art 15 .

98. Ibid art 3.

99. See the equivalent in the Fisheries Act (n 4) sch 11, ss 2(4), 2(13).

100. Identical to $\mathrm{s}$ 12(1) of the Fisheries Act ( $\mathrm{n}$ 4), anticipating the preservation of EU access to UK waters under the Trade and Cooperation Agreement (n 4) art 500(1), 500(4) and 500(5), including the belt 6 to $12 \mathrm{~nm}$ from the baseline.

101. UNCLOS (n 64) art 56. 
jurisdictional anomaly in the waters around the Svalbard archipelago, ${ }^{102}$ to which the Spitsbergen Treaty secured Norway's title, ${ }^{103}$ the quid pro quo being non-discriminatory access for nationals of other parties to that treaty, including the UK, in any economic activity on the islands or in their surrounding territorial sea. ${ }^{104}$ If so, the default position had the UK left the EU on 29 March 2019 without a withdrawal treaty would not have been the scenario painted in the White Paper, by which new long-term arrangements taking effect in 2021 need not be negotiated until $2020 .{ }^{105}$ Instead, the equal access of EU vessels to UK waters and vice versa would have ended abruptly on that date (except for vessels flagged to any of the five States benefiting from the 1964 Convention, for which it would have continued wholly or partly for a further 14 weeks), triggering the envisaged negotiations rather sooner.

\section{OMISSIONS FROM THE WHITE PAPER}

Conspicuously and curiously absent from the White Paper and the explanatory memorandum for the 2018 Bill, which devotes extensive space to the international fisheries law framework under UNCLOS and the UNFSA, is any mention of the third element of the trinity: the FAO Compliance Agreement. ${ }^{106}$ The EU is party to this treaty on behalf of, and to the exclusion of, its Member States; ${ }^{107}$ it requires national authorisation systems and keeping of records of vessels fishing on the high seas. ${ }^{108}$ In the EU's March 2020 draft treaty text, the FAO Compliance Agreement, alongside the Port State Measures Agreement which was also mentioned in the DEXEU guidance of early $2019,{ }^{109}$ is one of several international fisheries instruments with which the parties shall 'act consistent', ${ }^{110}$ a provision reworded but substantively retained in the Trade and Cooperation Agreement. ${ }^{111}$ The timing of the UK's acceptance of both Agreements (31 December 2020 according to the FCDO website, ${ }^{112} 1$ January 2021 for the Compliance Agreement according to the FAO, ${ }^{113}$ a discrepancy not accounted for by the final clauses of this treaty), suggests that, had the Trade and Cooperation Agreement remained unconcluded, they would have remained a low priority.

102. Robin Churchill and Geir Ulfstein, 'The Disputed Maritime Zones Around Svalbard' in Myron H Nordquist, Tomas H Heidar and John Norton Moore (eds), Changes in the Arctic Environment and the Law of the Sea (Martinus Nijhoff Publishers, Leiden 2010) 551, 565.

103. Treaty Concerning the Archipelago of Spitsbergen (adopted 9 February 1920, entered into force 14 August 1925) 2 LNTS 7 art 1.

104. Churchill and Ulfstein (n 102) 552-553.

105. White Paper (n 4) 17-18.

106. FAO Compliance Agreement (n 38).

107. For the full list of its 44 parties see Food and Agriculture Organization of the United Nations, 'FAO Treaties Database: Agreement to Promote Compliance with International Conservation and Management Measures by Fishing Vessels on the High Seas' <http://www. fao.org/treaties/results/details/en/c/TRE-000023/> accessed 7 April 2021.

108. FAO Compliance Agreement (n 38) arts III(2) and IV.

109. DEXEU List (n 36).

110. March Draft Text (n 10) art LPFS.2.45(3)(b).

111. Trade and Cooperation Agreement (n 4) art 404(2)(a).

112. UK Treaties Online <https://treaties.fco.gov.uk/awweb/awarchive?type=file \& item $=72011>$ and $<$ https://treaties.fco.gov.uk/awweb/awarchive?type=file \&item=79063> respectively, both accessed 7 April 2021.

113. FAO Treaties Database (n 107) with accompanying circular letter from the depositary <http://www.fao.org/treaties/results/details/en/c/TRE-000258/> accessed 7 April 2021. 
A possible reason for this is the small size of the UK distant-water fleet already noted, and that the FAO Compliance Agreement adds relatively little to the parallel and more elaborate UNFSA obligations by which the UK is already bound, for example the requirement to control its fleet through a system of licensing or authorisation based on regional or global procedures. ${ }^{114}$ Even had it not become bound by this treaty, the UK would have continued to observe the relevant rules to the extent that they fall within the bulk of the Regulation enacting the CFP ${ }^{115}$ not repealed by the Fisheries Act. ${ }^{116}$ In order to implement it, regulations are needed to prohibit unauthorised fishing on the high seas or in areas under the jurisdiction of other States, that is, foreign EEZs. The Fisheries Act has such a provision: s 14(1) prohibits fishing 'anywhere by a British fishing boat ... unless authorised by a licence'.

Another omission from the White Paper, if less obvious, is any recognition of the risk now that the UK is outside the EU that its internal maritime boundaries will from 2021 take on more significance than they previously had. Constitutionally, fisheries is in general a devolved matter, but international relations, including management of international fisheries, are an express exception. ${ }^{117}$ Hitherto, the government has apportioned UK quotas derived from bilateral agreements or through RFMOs to the four administrations as fixed quota allocation units under the 2012 Concordat on Management Arrangements for Fishing Opportunities and Fishing Vessel Licensing in the UK. ${ }^{118}$ Because the Concordat does not address management of stocks present on both sides of an internal boundary, since in 2012 these would have been expected to remain subject to uniform schemes of management under the CFP, the emergence of a situation where different harvesting strategies are pursued on opposite sides of such boundaries cannot be ruled out. Neither the White Paper nor the Fisheries Act makes any provision for dealing with such an eventuality.

\section{NAVIGATIONAL FREEDOM OF FOREIGN FISHING VESSELS IN THE UK EEZ}

The final noteworthy matter is one that appears for the first time in the Fisheries Act, without previous mention in the White Paper. This is the oddly roundabout way in which the presence of foreign fishing vessels in UK waters for purposes other than fishing is handled. There has long been a degree of tension in the EEZ between regulation of fishing, a matter for the coastal State alone, and the freedom of navigation preserved there, ${ }^{119}$ ordinarily including matters incidental to navigation. In 2014, however, the International Tribunal for the Law of the Sea (ITLOS) held that coastal State sovereign rights over fishing include the power to prohibit bunkering (refuelling) at sea of fishing vessels, a practice normally subsumed for other vessels within the freedom

114. UNFSA (n 42) art 18(3).

115. Regulation (EU) No 1380/2013 of the European Parliament and of the Council of 11 December 2013 on the Common Fisheries Policy, Amending Council Regulations (EC) No 1954/2003 and (EC) No 1224/2009 and Repealing Council Regulations (EC) No 2371/2002 and (EC) No 639/2004 and Council Decision 2004/585/EC, [2013] OJ L354/22.

116. Explanatory Notes (n 19) para 59.

117. Under the Scotland Act 1998 (UK), sch 5, pt I, para 7(1); Government of Wales Act 2006 (UK), sch 7A, paras 10(1) and (2); and the Northern Ireland Act 1998 (UK) sch 2, para 3.

118. Explanatory Notes (n 19) para 19.

119. UNCLOS (n 64) art 58(2). 
of navigation. ${ }^{120}$ It is rare for States to regulate the mere transit of fishing vessels through their EEZs; one known instance is a French requirement for fishing vessels to notify the local authorities of their presence in the EEZ, noted in passing in an earlier ITLOS case. ${ }^{121}$ It is therefore unexpected to find in the Fisheries Act drafting that appears to call into question foreign fishing vessels' right to pass through the UK EEZ; their access to lawfully exploitable fishing grounds elsewhere would be severely hampered if such transit were denied to them, a position that is not generally supported. But s 12(1) of the Fisheries Act provides that:

(1) A foreign fishing boat must not enter British fishery limits [that is, the UK EEZ ${ }^{122}$ ] except-

(a) for the purpose of fishing in accordance with a sea fishing licence, or

(b) for a purpose recognised by international law or by any international agreement or arrangement to which the United Kingdom is a party.

The first exception contemplates issuing to vessels of licences by the relevant UK authority, in apparent anticipation of agreements eventually being reached, as they now have been, on shared stocks with the EU and the UK's other neighbours, ${ }^{123}$ which will temper the exclusion of their vessels from the UK's EEZ that becomes possible with the CFP no longer applying, in return for continued ease of access to the EU market for the catches of the UK's own fishing fleet. It is the second exception that seems relevant: navigation is certainly a 'purpose recognised by international law', but the following subs (2) of s 12 ('a foreign fishing boat that enters British fishery limits for a purpose mentioned in subsection (1) must return outside British fishery limits as soon as the purpose has been fulfilled') risks proving excessively rigid. This is because it appears not to accommodate the common practice of mandatory post-fishing inspection of catch and gear in port to enforce compliance with licence conditions; potentially the UK might wish to insist on this under a future 'international agreement or arrangement to which the United Kingdom is a party' ${ }^{124}$ but that would be precluded if, unilaterally without negotiating such a framework, it decides to license any foreign fishing vessel ad hoc. Moreover, where transit itself is the purpose, its very

120. $M / V$ 'Virginia G' (Panama/Guinea-Bissau) (Judgment of 14 April 2014) ITLOS Reports 2014, 4.

121. The 'Monte Confurco' Case (Seychelles v France) (Prompt Release, Judgment of 18 December 2000) ITLOS Reports 2000, 86 [37].

122. The Fisheries Act (n 4) retains the term 'fishery limits' from the Fishery Limits Act 1976 (UK), which has survived the declaration of the EEZ under the Marine and Coastal Access Act 2009 (UK). The two can be taken as functionally synonymous apart from the geometric difference, trivial for present purposes, that one term refers to lines and the other to the area within those lines.

123. See Framework Agreement on Fisheries Between the United Kingdom of Great Britain and Northern Ireland and the Kingdom of Norway (signed 30 September 2020, provisionally applied from 1 January 2021) <https://assets.publishing.service.gov.uk/government/uploads/system/ uploads/attachment_data/file/927151/CS_Norway_1.2020_UK_Norway_Framework_Agreement_ on_Fisheries.pdf>; and Framework Agreement on Fisheries Between the Government of the United Kingdom of Great Britain and Northern Ireland and the Government of the Faroes (signed 29 October 2020) <https://assets.publishing.service.gov.uk/government/uploads/system/uploads/ attachment_data/file/933792/CS_Faroe_Islands_1.2020_UK_Faroes_Framework_Agreement_on_ Fisheries.pdf>. Neither treaty has yet entered into force.

124. No such requirement is laid down in the Trade and Cooperation Agreement (n 4), but nor does it inhibit the future institution of one. 
achievement takes the vessel outside the EEZ, and it is decidedly odd to impose this as an additional requirement.

Conversely, an opportunity has been missed: under a more flexible dispensation, while foreign fishing vessels entering the UK EEZ in exercise of the freedom of navigation cannot be obliged to disclose the quantity of fish in their holds, they could nevertheless be encouraged to report this tonnage to the authorities by a rebuttable presumption that the holds are empty if they do not. This could be useful in prosecuting vessels that subsequently come to the authorities' notice if unlicensed fishing activity is suspected, as may occur if, say, poor fishing conditions or weather prevent a Faroese vessel from filling its holds in its own EEZ, and en route to a European port via the shortest route, namely through the UK EEZ, it deploys its nets in the hope of making up the shortfall.

\section{CONCLUSION}

As befits the momentous nature of the UK's departure from the EU, the Fisheries Act and the White Paper that preceded it represent the most far-reaching overhaul for decades of the legal framework for marine capture fisheries. They could not of themselves eliminate the risk of economy-wide exigencies dictating that non-fisheries considerations intrude on the government's bargaining position, leading to acceptance of a fisheries settlement, whether in the Trade and Cooperation Agreement then still under negotiation or separately from it, much less advantageous to the UK than its stated preference in the White Paper for allocations based on zonal attachment. Even so, the two documents go most but potentially not all of the way to enacting the new measures required for the UK to discharge fully its international obligations; to the extent that the Fisheries Act falls short in this respect, it must be regretted that in the deliberative stages of its passage through Parliament the opportunity to make the ameliorative adjustments suggested above was not taken. 